Original articles

J. Perinat. Med.

13 (1985) 117

\section{Modern strategy for the term breech delivery - A study with a 4-year follow-up of the infants}

\author{
N. W. Svenningsen, M. Westgren, I. Ingemarsson
}

Departments of Pediatrics and Obstetrics and Gynecology, University Hospital, Lund, Sweden

\section{Introduction}

For many years the optimal mode of delivery for infants in breech presentation at birth has been a matter of great concern. In order to reduce the incidence of complications related to labor and to vaginal delivery several obstetricians have advocated wide indications for cesarean section.

In this context, however, a distinction should be made between preterm and term breech deliveries. Recently, several studies have demonstrated improved fetal outcome after abdominal preterm deliveries compared to vaginal deliveries and in this group of patients routine performance of cesarean sections are recommended $[5,10,20]$. On the other hand, opinions diverge about the ideal rate of cesarean section in term ( $>37$ weeks) breech deliveries. Thus a liberal use of cesarean section has been recommended by some authors [18] whereas by others it has been proposed as a routine procedure [19]. Earlier studies have evaluated the fetal outcome in terms of perinatal or neonatal complications but not the long-term morbidity and the rate of permanent neurological sequelae.

In the present investigation this important "end point" has been assessed by a scheduled pediatric follow-up of term breech infants for at least four years. During the period involved two different protocols for management of term deliveries were used resulting into different rates of cesarean sections.

\section{Material and methods}

From January 1st 1971 through December 31st 1977 a total number of 23979 singletons were born in the Obstetrical Department of the University Hospital in Lund. The total rate of breech deliveries was $3.4 \%$ ( 814 deliveries). Infants born preterm (before the 37th week of gestation), all twins and triplets, antenatal dead infants and infants with congenital malformations were excluded, i. e. the total number of term singleton breech delivered infants being 709.

The material was divided into two $31 / 2$-year periods with different obstetric management, period A (1st January 1971 through 31st May 1974)

period B (1st June 1974 through 31st December 1977).

\subsection{Obstetric and neonatal management}

During the two study periods term breech deliveries were managed according to two dif- 
ferent protocols. In period A pelvimetry with additional antero-posterior film of the abdomen was performed as a routine in primiparae. In period $B$ this procedure was made in all multiparae as well. The pelvimetry was performed according to the method of BorELL and FERNSTRÖM [2], i. e. an antero-posterior and a lateral film of the pelvis. The antero-posterior inlet diameter was measured. Thereafter the sum of the antero-posterior diameter of the outlet, bispinous and bituberal, was calculated.

In period $\mathrm{A}$ cesarean section was performed if the antero-posterior diameter of the inlet was less than $11 \mathrm{~cm}$ and/or the sum of the outlet was less than $32 \mathrm{~cm}$.

From 1974 in period B the criteria were changed as follows: cesarean section was performed if the antero-posterior diameter of the inlet was less than $12 \mathrm{~cm}$ or less than $2 \mathrm{~cm}$ above the biparietal diameter (BPD) measured with ultrasound; if the sum of the outlet was less than $33.5 \mathrm{~cm}$ or if the estimated birthweight (clinically) was more than $4000 \mathrm{~g}$. Finally, at the end of period B (1977) hyperextension of the fetal head became an additional indication for cesarean section.

In both periods cesarean section was performed in every case with serious pregnancy complications, signs of dysfunctional labor or fetal distress.

In period $A$ and $B$ vaginal breech deliveries were managed as follows: all types of breech presentations were handled in the same way. Due to impending risk of umbilical cord prolapse as well as lack of cervical dilatation of forewater, amniotomy was avoided. Spontaneous delivery of the breech just past the umbilicus was permitted, followed by a manual rotation of the shoulders for delivery of the arms and head. At extended arms LövSETS maneuver was used. The aftercoming head was, if required, delivered by the method of VEITSMellie-MAURICEAU or rarely by PIPER forceps. A generous episiotomy was performed by routine. Delivery anesthesia was usually pudendal block. Vaginal delivery was assisted by a midwife and a resident, under the super- vision of a senior house 'officer. There was anesthesia coverage of each delivery and a neonatologist was in attendance at delivery. Electronic fetal monitoring has been a routine procedure at breech presentation at our clinic since 1972 [23]. Routine ultrasonic examinations and evaluation of the BPD were introduced in 1974.

In the maternity ward all newborn infants were examined by the neonatologist on the first day of life and reexamined at discharge on day 5 according to a standardized protocol including physical and neurological examination and assessment of maturity [7]. Infant requiring observation or transitional care in the neonatal unit were examined likewise.

\subsection{Follow-up examinations}

At 2 years of age neurological examination and development evaluation were performed in the pediatric outpatient clinic or the child health care center according to neurodevelopmental scales for Swedish children. In infants with late speech or late psychomotor development audiometry tests were also made.

At 4 years of age the children were reexamined with a comprehensive health examination including a thorough physical check-up by an experienced pediatrician and screening of vision, hearing, bacteriuria and behaviour problems. Children with health problems were referred for further evaluation by specialists at the University Hospital of Lund.

Neurodevelopmental abnormalities were classified as follows: Cerebral palsy (Cp) comprises syndromes of hemi-, tetra- and diplegia or dyskinetic/ataxic syndrome, i. e. incoordinated hyperkinetic movements, unsteady gait and intention tremor. In early infancy these children often showed dystonic traits, tension shifts, and persistent neonatal reflexes. Minimal brain dysfunction (MBD) was classified at the 4-year examination as children showing hyperactivity and distractibility combined with general clumsiness but without additional neurological signs. Psychomotor retardation (PMR) was dia- 
gnosed at the 2-year examination in children who could not walk and had late speech development and at 4 years of age in children with mental retardation (IQ $\leq 70$ ). Epilepsy was diagnosed in children with repeated seizures unrelated to febrile disorders.

The 4-year examination was supplemented with questionnaires to the parents regarding the child's development, previous and present health problems and also the family's social and educational standard. The details of these procedures have been described extensively in previous reports [13].

In the 4-year examination the breech delivered singletons were compared with a control group of 1201 vaginally born fullterm singletons in vertex position from an earlier follow-up study of such infants born 1973-75 in the maternity hospital in Lund [14].

Statistical comparisons were performed by Chisquare analyses with YATES' correction whenever applicable.

\section{Results}

The material comprises 709 term singleton breech presentation deliveries. The number of infants, mode of delivery and the neonatal mortality in the two study periods A and B are presented in Tab. I. In period $B$ the rate of cesarean section rose to $37.1 \%$ from previously $16.9 \%$.

Only two infants died; none intrapartum. In period A one infant died after a traumatic delivery, the aftercoming head being trapped in the cervix. The infant had severe asphyxia and died 18 hours after birth. Postmortem examination showed large intracranial hemorrhages. In period B one infant died at three weeks of age in the sudden infant death syndrome. The need for transitional care in the neonatal unit was lower in period $\mathrm{B}(8.9 \%)$ than in period $\mathrm{A}$ $(14.8 \%)$.

\subsection{Follow-up at 2 years of age}

Six hundred and thirty-nine of 707 survivors could be examined in our 2-year follow-up study. Sixty-eight infants had moved out of the region and could therefore not be reexamined.

The rate of developmental handicaps is shown in Tab. II being $4.6 \%$ in period $\mathrm{A}$ and $1.5 \%$ in period $\mathrm{B}$. The difference was mainly due to a lower incidence of sequelae in vaginally born infants during period B compared to period A. The sequelae rate was low in the cesarean section groups in both periods. Tab. III gives obstetric data of the infants with neurological sequelae at 2 years of age. Pregnancy complications were rare. Pelvimetry was performed in 15 patients. Obstetric complications occurred

Tab. I. Rate of cesarean section and number of neonatal deaths, number of infants treated in neonatal unit and participants in the follow-up study of 709 term, singleton presented by the breech. (N.S. = not significant)

\begin{tabular}{lccc}
\hline & $\begin{array}{c}\text { Period A } \\
(\mathrm{n}=330)\end{array}$ & $\begin{array}{c}\text { Period B } \\
(\mathrm{n}=379)\end{array}$ & p-value \\
\hline $\begin{array}{l}\text { Cesarean sections (\%) } \\
\quad \text { Emergency }\end{array}$ & 10 & & \\
$\quad$ Elective & 46 & 15 & \\
$\quad$ Total & $56(16.9)$ & $\frac{126}{141(37.1)}$ & $<0.01$ \\
Transitional care in the neonatal unit (\%) & $49(14.8)$ & $34(8.9)$ & $<0.05$ \\
Neonatal deaths (0-28 days) (\%) & $1(0.3)$ & $1(0.3)$ & N.S. \\
Survivors & 329 & 378 & \\
Follow-up at 2 years of age & 300 & 339 & \\
Follow-up at 4 years of age & 233 & 247 & \\
\hline
\end{tabular}


Tab. II: Neurodevelopmental sequelae at 2 years of age in 639 breech born infants. (VD = vaginal delivery, $\mathrm{CS}=$ cesarean section)

\begin{tabular}{lcccc}
\hline & \multicolumn{2}{c}{$\begin{array}{c}\text { Period A } \\
\text { (n=300) }\end{array}$} & \multicolumn{2}{c}{$\begin{array}{l}\text { Period B } \\
\text { (n=339) }\end{array}$} \\
& VD & CS & VD & CS \\
\hline $\begin{array}{l}\text { Number of infants } \\
\begin{array}{l}\text { Cerebral palsy } \\
\text { tetraplegia }\end{array}\end{array}$ & 246 & 54 & 201 & 138 \\
$\quad$ hemiplegia & 2 & & 1 & \\
$\quad \begin{array}{l}\text { diplegia } \\
\text { dyskinetic/ataxia }\end{array}$ & 2 & & & \\
$\begin{array}{l}\text { Erb's palsy } \\
\text { Psychomotor retardation }\end{array}$ & 2 & & 1 & 1 \\
$\begin{array}{l}\text { Total } \\
\text { \% }\end{array}$ & 2 & & 1 & \\
(\%) in each period & 14 & 0 & 4 & 1 \\
\hline
\end{tabular}

p-values: A vs. B N.S.

in a majority of the cases i. e. in 14 of the 18 vaginally delivered patients. Two infants were small for gestational age; none had a birthweight exceeding $4000 \mathrm{~g}$. Footling presentation was overrepresented in the infants with neurological handicaps.

\subsection{Follow-up at 4 years of age}

At 4 years of age 480 children were reexamined as described earlier. As shown in Tab. IV the total rate of neurological sequelae was higher in period $\mathrm{A}$ than in period $\mathrm{B}$. This was mainly due to the higher incidence of cerebral palsy syndromes among the vaginally delivered infants. They had all been diagnosed at the 2year control examination (Tab. II). The total incidence of neurological sequelae was $5.3 \%$ in period $A, 2.4 \%$ in period $B$ and $1.5 \%$ in the vertex delivered group. The difference between period $A$ and vertex infants is statistically significant $(\mathrm{p}<0.05)$.

The rate of visual and auditory disorders did not differ significantly between the study groups (Tab. V). The figures for considerable behaviour problems, enuresis and very late speech development were similar in all three groups (Tab. VI).

\section{Discussion}

The long-term outcome in the present study is the result of different protocols for the management of term infants in breech presentation. However, the two protocols were applied in two consecutive time periods with changes in the obstetric and neonatal management in general as in period $\mathrm{A}$ (cesarean section rate $16.1 \%$ ) the perinatal management was more conservative than in period $B$ (cesarean section rate $37.1 \%$ ) with a more active obstetric and neonatal care. Besides a lower need for transitional neonatal care during period $\mathrm{B}$ no differences were seen in overall neonatal mortality and morbidity.

In total 639 infants were reexamined at two years of age (Tab. II). Nineteen infánts had handicaps and 18 of these were born vaginally. In period $A$ all 14 infants with sequelae were vaginally delivered and pelvimetry was made in 11 mothers. Only one of these (A 4) had a pelvic outlet sum less than $33.5 \mathrm{~cm}$. On the other hand, 6 patients had an inlet diameter of less than $12 \mathrm{~cm}$ resulting in difficult descent of the fetal head in two patients (A 6, A 12). With the period $B$ criteria for vaginal delivery all of these patients probably had been abdominally delivered. Three period A vaginally born infants with hyperextension of the head had severe cerebral sequelae. They all fulfilled the criteria for cesarean section used at the end of period $\mathrm{B}$.

From period A 233 children were examined also at 4 years of age. Neurodevelopmental sequelae were found in $5.3 \%$ but the difference between the vaginal delivery and cesarean section groups was only moderate (Tab. IV). The rate of these sequelae, however, was more than thrice that for vertex infants. In period $A$ the incidence of visual and auditory disorders, behaviour problems, enuresis and very late speech development (Tabs. V, VI) were not higher than in the vertex infants. The neurodevelopmental sequelae in group A infants could in most cases be related to labor problems such as footling, hyperextension of the fetal head and/or inadequate antero-posterior diameter at the brim. It seems reasonable to suppose that some of 


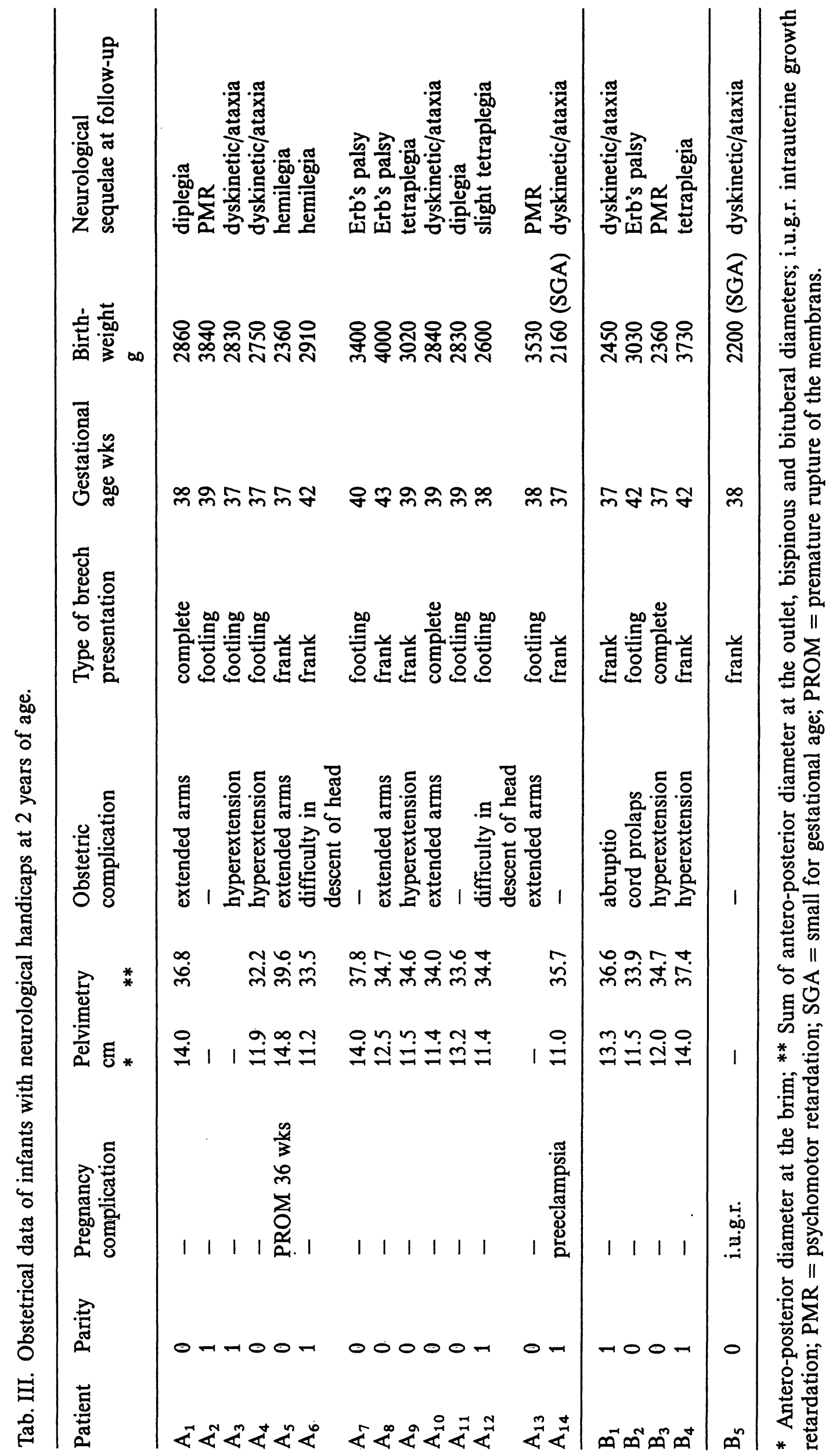


Tab. IV. Neurodevelopmental sequelae at 4 years of age in 480 breech born infants. (VD = vaginal delivery; CS = cesarean section; $\mathrm{MBD}=$ minimal brain damage)

\begin{tabular}{|c|c|c|c|c|c|}
\hline & \multicolumn{2}{|c|}{$\begin{array}{l}\text { Period A } \\
(\mathrm{n}=233)\end{array}$} & \multicolumn{2}{|c|}{$\begin{array}{l}\text { Period B } \\
(\mathrm{n}=247)\end{array}$} & $\begin{array}{l}\text { Vertex } \\
(\mathrm{n}=1202) \\
\text { VD }\end{array}$ \\
\hline $\begin{array}{l}\text { Number of infants } \\
\text { Cerebral palsy } \\
\text { Psychomotor retardation } \\
\text { MBD-syndrome } \\
\text { Epilepsy }\end{array}$ & $\begin{array}{r}185 \\
5 \\
2 \\
3 \\
1 \\
\end{array}$ & $\begin{array}{l}1 \\
1\end{array}$ & $\begin{array}{r}155 \\
2 \\
1 \\
1\end{array}$ & $\begin{array}{r}92 \\
1\end{array}$ & $\begin{array}{r}1202 \\
3 \\
4 \\
10 \\
1 \\
\end{array}$ \\
\hline $\begin{array}{l}\text { Total } \\
\% \\
(\%) \text { in each period }\end{array}$ & $\begin{array}{r}11 \\
6.0\end{array}$ & $\begin{array}{l}2 \\
4.2\end{array}$ & $\begin{array}{l}4 \\
2.9\end{array}$ & $\begin{array}{l}2 \\
2.2\end{array}$ & $\begin{array}{l}18 \\
1.5 \\
(1.5)\end{array}$ \\
\hline
\end{tabular}

p-values: A vs. B N.S.; A vs. vertex $<0.05$; B vs. vertex N.S.

Tab. V. Visual and auditory disorders at 4 years of age in 480 breech born infants. (VD = vaginal delivery, CS $=$ cesarean section)

\begin{tabular}{|c|c|c|c|c|c|}
\hline & \multicolumn{2}{|c|}{$\begin{array}{l}\text { Period A } \\
(n=233)\end{array}$} & \multicolumn{2}{|c|}{$\begin{array}{l}\text { Period B } \\
(\mathrm{n}=247)\end{array}$} & \multirow{2}{*}{$\begin{array}{l}\text { Vertex } \\
(n=1202) \\
\text { VD }\end{array}$} \\
\hline & VD & $\mathrm{CS}$ & VD & $\mathrm{CS}$ & \\
\hline Number of infants & 185 & 48 & 155 & 92 & 1202 \\
\hline \multicolumn{6}{|l|}{ Visual disorders } \\
\hline Strabism & 5 & 2 & 4 & 2 & 39 \\
\hline Refractory errors & 11 & 2 & 4 & 6 & 82 \\
\hline Total & 16 & 4 & 8 & 8 & 121 \\
\hline & 8.7 & 8.3 & 5.2 & 8.7 & 10.1 \\
\hline$(\%)$ in each period & \multicolumn{2}{|c|}{$(8.6)$} & \multicolumn{2}{|c|}{$(6.5)$} & $(10.1)$ \\
\hline \multicolumn{6}{|l|}{ Auditory disorders } \\
\hline Sensorineural & 2 & 1 & 2 & 。 & 3 \\
\hline Conductive & 4 & 2 & 1 & 2 & 27 \\
\hline Total & 6 & 3 & 3 & 2 & 30 \\
\hline$\%$ & 3.2 & 6.3 & 1.9 & 2.2 & 2.5 \\
\hline$(\%)$ in each period & \multicolumn{2}{|c|}{ (3.9) } & \multicolumn{2}{|c|}{$(2.0)$} & $(2.5)$ \\
\hline
\end{tabular}

p-values: A vs. B N.S.; A vs. vertex N.S.; B vs. vertex N.S.

these sequelae could have been avoided by following the period B principles.

In period B only five infants were handicapped at 2 years of age. One of these had intrauterine growth retardation (cesarean section) and the other four (vaginal delivery) had complications in labor (Tab. III). In two cases the X-ray investigation during labor demonstrated hyperextension of the fetal head as also found in 3 period $\mathrm{A}$ infants with neurological handicaps. Earlier studies have shown a $20 \%$ incidence of neurological sequelae in infants with hyperextended head in vaginal delivery [3]. A previous study from our clinic showed that one fifth of vaginally delivered infants were damaged if hyperextension was demonstrated in labor but none if delivered abdominally [22]. The importance of this complication is obvious in group B, as two of four vaginally delivered 
Tab. VI. Enuresis, behaviour and very late speech problems at 4 years of age in 480 breech born infants. (VD = vaginal delivery, $\mathrm{CS}=$ cesarean section)

\begin{tabular}{|c|c|c|c|c|c|}
\hline & \multicolumn{2}{|c|}{$\begin{array}{l}\text { Period A } \\
(\mathrm{n}=233) \\
\text { VD }\end{array}$} & \multicolumn{2}{|c|}{$\begin{array}{l}\text { Period B } \\
(n=247)\end{array}$} & $\begin{array}{l}\text { Vertex } \\
(\mathrm{n}=1202) \\
\text { VD }\end{array}$ \\
\hline $\begin{array}{l}\text { Number of infants } \\
\text { Enuresis } \\
\% \\
(\%) \text { in each period }\end{array}$ & $\begin{array}{l}185 \\
19 \\
10.2\end{array}$ & $\begin{array}{l}48 \\
6 \\
12.5 \\
7)\end{array}$ & $\begin{array}{r}155 \\
11 \\
7.1\end{array}$ & $\begin{array}{l}92 \\
4 \\
4.3 \\
4\end{array}$ & $\begin{array}{c}1202 \\
108 \\
9.0 \\
(9.0)\end{array}$ \\
\hline $\begin{array}{l}\text { Considerable behaviour problems } \\
\% \\
(\%) \text { in each period }\end{array}$ & $\begin{array}{l}7 \\
3.8\end{array}$ & 3 & $\begin{array}{l}5 \\
3.2\end{array}$ & $\begin{array}{l}4 \\
4.3\end{array}$ & $\begin{array}{l}89 \\
7.4 \\
(7.4)\end{array}$ \\
\hline $\begin{array}{l}\text { Very late speech development } \\
\% \\
(\%) \text { in each period }\end{array}$ & $\begin{array}{l}4 \\
2.2\end{array}$ & 2.1 & $\begin{array}{l}3 \\
1.9\end{array}$ & $\begin{array}{l}1 \\
1.1\end{array}$ & $\begin{array}{l}12 \\
1.0 \\
(1.0)\end{array}$ \\
\hline
\end{tabular}

p-values: A vs. B, A vs. vertex, B vs. vertex all N.S.

children with later handicaps had hyperextended head in labor. It is postulated that their handicaps might have been avoided by abdominal delivery. If these two vaginally delivered infants with extended head are excluded only 4 handicapped infants (4 out of $247=$ $1.6 \%$ ) remain at the 4-year follow-up (Tab. IV). This incidence is identical to that of the vertex delivery group $(1.5 \%)$.

The mode of delivery of fetuses in breech presentation at term has been studied by several authors $[8,12,15]$. However, only a few investigations were made prospectively $[11,17]$ and, to our knowledge, only one is correctly randomized [4]. The cesarean section rate vary in these studies from $19 \%$ to $71 \%$. In agreement with our findings these authors conclude that judiciously selected fetuses in term breech presentation may be safely delivered vaginally by a selective management protocol requiring cesarean section only when mandatory criteria are not met.

There are only few follow-up studies of breech infants born at term. BERENDES [1] studying infants with birthweights above $2500 \mathrm{~g}$ found at one year of age no difference in morbidity between a group of breech and of non-breech infants. On the other hand, TALLIAN et al. [21] found an incidence of mental deficiency and neurological abnormalities twice as high in breech born term infants as in a vertex group at 6 to 12 years of age.

Some data on the long-term prognosis have been published by FIANU et al. [6]. They analyzed questionnaires sent to parents and teachers of 1106 breech born children in a comparison with children born in vertex presentation. In children with birthweights more than $2500 \mathrm{~g}$ they found a 7 -fold increase in the incidence of hyperkinesia and learning disability compared to the vertex presentation group. Still these data were obtained from questionnaires and not by a physical and neurodevelopmental examination of each child as performed in the present investigation.

In a critical survey of the above mentioned and other follow-up studies MANZKE [16] stated that most of these studies have serious shortcomings since they are mostly based on questionnaires. Therefore it is not surprising that the results vary considerably. They often deal with too small or heterogenous composite material and often lack an adequate control group. Furthermore, they present data from patients managed according to obstetric principles of the 1960 s with cesarean section rates about $5 \%$ 
to $15 \%$. In contrast to TALLIAN et al. [21] and FIANU et al. [6] the present 4-year follow-up examination found no differences between term breech and vertex deliveries.

Our results indicate that vaginal delivery in strictly selected cases of breech deliveries can be performed with a minimum risk for the infant. This selection is based on routine X-ray pelvimetry and ultrasound fetal cephalometry performed together with an X-ray film of the position of the fetal head at the admission before vaginal delivery. With this policy a major part of the infants were born vaginally in period $\mathrm{B}$ with a cesarean section rate of $37.1 \%$. The rate of mortality and the long-term outcome in the vaginally delivered term breeches did not differ from the cesarean deliveries. Our results are in accordance with the findings of HOCHULI et al. [9] who also used routine X-ray pelvimetry and ultrasound fetal cephalometry in breech deliveries. With a cesarean section rate of $34.4 \%$ they found no difference in mortality and morbidity in infants born vaginally or by cesarean section.

Data available in the literature do not settle the question of the optimum rate of cesarean section in term breeches. The present results indicate, however, that the long-term outcome of the term breech born infant is not different from a vertex born infant if modern principles are adopted. In our population this policy resulted in a cesarean section rate of $37.1 \%$. It seems doubtful that a further increase of the cesarean section rate could improve the longterm outcome of term breech born infants.

\section{Summary}

In a comprehensive 4-year follow-up study the longterm outcomes in 709 singleton term breech born infants were evaluated.

The outcome has been related to different management protocols during two consecutive study periods. In the first period (A, 1971-1974) the rate of cesarean section was $16.1 \%$ and in the second period $(B, 1974-1977)$ $37.1 \%$.

The neonatal mortality rate was the same in both study periods $(0.3 \%)$. The incidence of long-term neurodevelopmental handicaps was in period A $5.3 \%$ and in period B $2.4 \%$ at 4 years of age. Sequelae among infants in period $\mathrm{A}$ were in most cases labor-related, i. e. footling, extended arms or difficulty in descent of the fetal head. An antern-posterior diameter of less than $12 \mathrm{~cm}$ at the brim was common in these cases. In both study periods there was an increased risk of neurodevelopmental handicaps for infants with hyperextension of the head in the breech position delivered by the vaginal route.

In period $B$ the incidence of neurodevelopmental sequelae at the 4-year follow-up did not differ from that found in a group of infants born vaginally in vertex presentation.

The rates of visual and auditory disorders, behaviour problems, enuresis and late speech development were not increased in the breeches neither in period A nor in period $\mathrm{B}$.

It is concluded that a further increase of the cesarean section rate in order to improve the fetal outcome must be questioned.

Keywords: Breech delivery, cesarean section, cerebral palsy, psychomotor retardation.

\section{Zusammenfassung}

Moderne Leitung der BEL-Geburt - Nachuntersuchungen der Kinder im 4. Lebensjahr

In einer 4-Jahre-Nachuntersuchungsstudie wurden die Langzeitergebnisse von 709 aus Beckenendlage geborenen Kindern untersucht.

Das Ergebnis wurde $\mathrm{zu}$ der Geburtsleitung während zweier konsekutiver Untersuchungsperioden in Beziehung gesetzt. In der 1. Periode (A, 1971-1974) war die Schnittentbindungsfrequenz $16,1 \%$, in der 2 . Periode $(B$, 1974-1977) $37,1 \%$.
Die neonatale Mortalität war unverändert in beiden Zeitperioden $(0,3 \%)$. Die Häufigkeit von späten neurologischen Auffälligkeiten im Alter von 4 Jahren war in der Periode A 5,3\% und in der Periode B 2,4\%. Folgezustände bei Kindern der Periode $A$ waren meistens abhängig von Komplikationen bei der Geburt, z. B. Fußlage, hochgeschlagene Arme oder Schwierigkeiten beim Durchtritt des Kopfes. Ein gerader Beckeneingangsdurchmesser von weniger als $12 \mathrm{~cm}$ war bei diesen Fällen häufig. In beiden Perioden war das Risiko neuro- 
logischer Auffälligkeiten erhöht, wenn Beckenendlagen mit zusätzlicher Hyperextension des Kopfes vaginal entwickelt wurden.

In der Periode B war die Häufigkeit neurologischer Auffälligkeiten bei der 4-Jahre-Nachuntersuchung nicht verschieden von einer Kontrollgruppe von Kindern, die aus Schädellagen entwickelt wurden.
Die Häufigkeit von audio-visomotorischen Störungen, Enuresis, Verhaltensproblemen und verzögerter Sprachentwicklung war bei Beckenendlagen weder in der Periode $A$ noch in der Periode B erhöht.

Als Schlußfolgerung der Studie ist in Frage zu stellen, ob eine weitere Erhöhung der Schnittentbindungsfrequenz die Langzeitergebnisse verbessern kann.

Schlüsselwörter: Beckenendlage, Cerebrale Parese, Psychomotorische Entwicklung, Schnittentbindung.

\section{Résumé}

La stratégie moderne de l'accouchement en présentation du bassin - Etudes de la surveillance d'enfants âgés de 4 ans

Dans une vaste étude poursuivie pendant 4 ans, nous avons évalué les conséquences à long terme, chez 709 nouveaux-nés unipares nés à terme en présentation du bassin.

Nous avons relaté les conséquences à différents protocoles de conduite pendant deux périodes d'étude consécutives. Dans la première période $(A, 1971-1974)$ la proportion de sections césariennes était de $16.1 \%$ et dans la seconde période $(\mathrm{B}, 1974-1977)$ de $37.1 \%$.

La proportion de mortalité néonatale était la même dans les deux périodes d'étude $(0.3 \%)$. L'incidence de handicaps dans le développement neurologique à long terme était dans la période $\mathrm{A}$ de $5.3 \%$ et dans la période $\mathrm{B}$ de $2.4 \%$ à l'age de 4 ans. Les séquelles parmi les nouveaux-nés de la période $\mathrm{A}$ étaient dans la plupart des cas reliées au travail, c'est à dire: présentation par les pieds, bras étendus ou difficulté de descente de la tête fœtale. Un diamètre antério-postérieur (entre la symphise pubienne et le sacrum), inférieur à $12 \mathrm{~cm}$ était commun dans ces cas. Dans les deux périodes d'étude, il y avait une augmentation de risque de handicaps dans le développement neurologique chez les nouveaux-nés en présentation du bassin avec hyperextension de la tête s'ils étaient accouchés par la voie vaginale.

Dans la période $B$, l'incidence des séquelles dans le développement neurologique poursuivies pendant 4 ans, ne différait pas de celle trouvée dans un groupe de nouveaux-nés accouchés vaginalement en présentation de la tête.

Les proportions de désordres visuels et auditifs, de problèmes de comportement, d'enuresis et de développement tardif de la parole, n'étaient augmentées dans les présentations du bassin ni dans la période $\mathrm{A}$, ni dans la période $B$.

Nous concluons qu'une plus ample augmentation de la proportion de sections césariennes afin d'améliorer les conséquences fotales, doit être remise en question.

Mots-clés: Développement neurologique, paralysie cérébrale, présentation du bassin, section césarienne.

Acknowledgements: Grants obtained from the Research Foundation of Margaretahemmet and Allmänna BB. The Swedish Medical Research Council grants no. B84-19X-04732-09A and K84-17F-6945-01.

\section{Bibliography}

[1] BERENDES, H.: Obstetrical complications and mental deficiency. International Copenhagen Congress on the Scientific Study of Mental Retardation 1 (1964) 308

[2] BORELL, U., I. FERnSTRÖM: Radiologic pelvimetry. Acta Radiol. Suppl. 191 (1960)

[3] Caterini, H., A. Langer, J. Sada et al.: Fetal risk in hyperextension of the fetal head in breech presentation. Am. J. Obstet. Gynecol. 123 (1975) 632

[4] Collea, J., C. Chein, E. J. Quilligan: The randomized management of term frank breech presentation. A study of 208 cases. Am. J. Obstet. Gynecol. 137 (1980) 235
[5] Duenhoelter, J., E. Wells, J. Reisch, et al.: A paired controlled study of vaginal and abdominal delivery of the low birth weight breech fetus. Obstet. Gynecol. 54 (1979) 310

[6] Fianu, S., I. Joelsson: Minimal brain dysfunction in children born in breech presentation. Acta Obstet. Gynecol. Scand. 58 (1979) 295

[7] FInNSTRÖM, O.: Studies of maturity in newborn infants. VI. Comparison between different methods for maturity estimation. Acta Paediatr. Scand. 61 (1972) 33

[8] Grmovsky, M., R. Petrie, D. Todd: Neonatal performance of the selected term vaginal breech delivery. Obstet. Gynecol. 56 (1980) 687 
[9] Hochuli, E., E. Dubler, E. Bornhauser, et al.: Die kindliche Entwicklung nach vaginaler und abdominaler Entbindung bei Beckenendlagen. Geburtshilfe Frauenheilkd. 37 (1977) 4

[10] Ingemarsson, I., M. Westgren, N. W. SVENNINGSEN: Long-term follow-up of preterm infants in breech presentation delivered by cesarean section. A prospective study. Lancet 2 (1978) 172

[11] Jaffa, A., M. Peyser, S. Ballas, et al: Management of term breech presentation in primigravidae. Br. J. Obstet. Gynaecol. 88 (1981) 721

[12] KaUPPILA, O.: The perinatal mortality in breech deliveries, and observations on affecting factors. A retrospective study on 2227 cases. Acta Obstet. Gynecol. Scand. Suppl. 39 (1975) 9

[13] KöHLER, L.: Health control of four-year-old children. An epidemiological study of child health. Acta Paediatr. Scand. Suppl. 235 (1973)

[14] KöHLER, L., N. SVENNINGSEN, B. LiNDQUist: Early detection of preschool health problems-role of perinatal risk factors. Acta Paediatr. Scand. 68 (1979) 229

[15] Lewis, B. W., H. R. Seneviratne: Vaginal breech delivery or cesarean section. Am. J. Obstet. Gynecol. 134 (1979) 615

[16] MANZKE, H.: Morbidity among infants born in breech presentation. J. Perinat. Med. 6 (1978) 127
[17] O'LeARY, J. A.: Vaginal delivery of the term breech. Obstet. Gynecol. 53 (1979) 341

[18] Rovinsky, J., J. MilleR, S. KAPlan: Management of breech presentation at term. Am. J. Obstet. Gynecol. 115 (1973) 497

[19] Smale, E.; M. Guico, C. Ensminger: Difficulties in breech delivery. Clin. Obstet. Gynecol. 19 (1976) 587

[20] Smith, M., S. Spencer, D. Hull: Mode of delivery and survival in babies weighing less than $2000 \mathrm{~g}$ at birth. Br. Med. J. 281 (1980) 1118

[21] Tallian, F., A. PứKKas, I. HeRnady, et al.: Über die Wirkung der Beckenendgeburt. Acta Chir. Hung. 6 (1965) 375

[22] Westgren, M., H. Grundsell, I. Ingemarsson,

et al.: Hyperextension of the fetal head in breech presentation: A study with long-term follow-up. Br. J. Obstet. Gynaecol. 88 (1981) 101

[23] Westgren, M., E. INGEMARsSon, I. INGEMARSSON, T. Solum: Intrapartum electronic fetal monitoring in low-risk pregnancies. Obstet. Gynecol. 56 (1980) 301

Received September 27, 1983. Revised April 19, 1984. Accepted June 15, 1984.

Dr. N. W. Svenningsen Department of Pediatrics University Hospital S-221 85 Lund, Sweden 